\title{
Correlation of Water Quality with Microplastic Exposure Prevalence in Tilapia (Oreochromis niloticus)
}

\author{
Desy Aryani ${ }^{1}$, Muta Ali Khalifa $^{* 1}$, Muhammad Herjayanto ${ }^{1}$, Ginanjar Pratama $^{1}$, Ani Rahmawati $^{1}$, Risandi Dwirama \\ Putra $^{2}$, Erik Munandar ${ }^{1}$ \\ ${ }^{1}$ Departement of Fisheries, Faculty of Agriculture, University of Sultan Ageng Tirtayasa, Jl. Raya Palka Km. 03 Sindangsari, \\ Kecamatan Pabuaran Kabupaten Serang Provinsi Banten, Indonesia \\ ${ }^{2}$ Shipping Engineering Department, Faculty of Technic, Maritime Raja Ali Haji University, Jl. Politeknik Senggarang, Senggarang, \\ Kota Tanjungpinang, Provinsi Kepulauan Riau, Indonesia
}

\begin{abstract}
The highly use of polyethylene plastics in Indonesia has negative impact toward freshwater aquaculture systems. Omnivorous fish is one of the freshwater biota that exposed by microplastics. This study aims to determine the effect of microplastics to water quality and the prevalence of microplastic exposure in tilapia. The experimental design is conducted using a microplastic exposure (polyethylene scrub) with concentration of $0.01 \mathrm{~g} / \mathrm{L}(\mathrm{P} 1), 0.1 \mathrm{~g} / \mathrm{L}(\mathrm{P} 2)$, and $1 \mathrm{~g} / \mathrm{L}$ (P3). Each treatment is repeated 3 times. The organ groups observed are the gastrointestinal, liver, gills, and gonads. The stages of the research including fish raising, microplastic extraction, water quality measuring parameter, and counting the amount of microplastics. The result obtained for water quality parameter is temperature, $\mathrm{pH}$, and dissolved oxygen still within safe fish farming limit. Microplastics at high concentration in water can cause a decrease in the total value of ammonia and do not affect the value of water temperature, $\mathrm{pH}$, and dissolved oxygen. Microplastics are found in the digestive organs, liver, gills, and gonads. The digestive tract of tilapia is the organ with the most microplastics after 14 days of exposure. It is concluded that microplastic is harmful for the life of tilapia because it can absorb to the liver and gonads.
\end{abstract}

\section{Introduction}

Microplastics (MPs) has become one of the environmental problems in the world [1]. Microplastics can contaminate the waters [2], sediments [3], soil [4], animals [5], plants [6], and even humans. This problem is very dangerous since microplastics can be absorbed to animals' tissues and cells and causing bioaccumulation [7]. The biggest degradation of plastic debris occurs in waters due to current and friction causing the particles to occur become microscopic [8]. The spread of plastic debris in the aquatic environment makes the entire ecosystem unbalanced. This opinion is known based on a research [9] that most degraded plastic debris have lower density than water so that the waste will float in the water column like plankton that flow along with the water current.

The spread of microplastics comes from several industrial and household wastes that are not properly processed [10]. In addition, pollution occurs due to a large number of industrial and household plastic waste that is directly dumped into the waters, especially rivers [8]. Based on empirical experience the river becomes a dumping ground by the Indonesian society. This habit causes aquatic biota become rare even endangered [11]. Some reservoirs that used for cultivation are also exposed to microplastics, for example, the Jatiluhur reservoir. [12] It is reported that the microplastics found in Jatiluhur reservoir is as much as $2.58 \times 105$ particles $\mathrm{Km} 2$ and the most common type of microplastics is polyethylene.

The use of polyethylene plastics in Indonesia is very high, many packaging products use polyethylene plastic [10]. This plastic effect also occurs in freshwater aquaculture systems [13], some of the fish that oftenly exposed by microplastics exposed are omnivorous fish [14]. One of the most consumed omnivorous fish in Indonesia tilapia. This fish is induced from Africa and has become one of the freshwater fish commodities that are widely traded in Indonesia because it is easy to cultivate and scrumptious [15]. Several studies have been conducted with results showing the presence of pollution caused by microplastics in the aquatic environment, but not many has discussed about the corelation between microplastics and water quality. In addition, there is still lack of data related to microplastic exposure to consumption fish, such as tilapia, as the basis for food safety. This study aims to determine the effect of microplastics on water quality and the prevalence of microplastic exposure in several organs of tilapia.

\footnotetext{
*Corresponding Author, e-mail: ma.khalifa@untirta.ac.id
} 


\section{Materials and methods}

\subsection{Material}

The main material used is tilapia (Oreochromis niloticus) from fish farmers in the region Pandeglang, Banten. Other materials used are distilled water, polyethylene scrub (Ningbo Sanbang Home Products Co. Ltd), $\mathrm{OH}$ (Merck), and H2O2 (Merck). Pisciculture used an aquarium of 12 pieces sized $100 \mathrm{~L}$. The instruments used are a microscope (Olympus CX-21), multitester for measurement DO and temperature (Lutron DO-5510), pH Meter (PCE-PHD 1), and ammonia test-kit (TETRA Ammonia Test).

\subsection{Methods}

This research is done in several stages, the first is fish treatment, water quality parameter measurement, microplastics extraction, number of microplastics calculation and the last is data analysis. The research design is experimental.

\subsection{Research design}

This study is an experimental study with randomized block design. The treatment given wass the difference of polyethylene microplastics scrub concentration, P1 with a microplastic concentration of $0.01 \mathrm{~g} / \mathrm{L}, \mathrm{P} 2$ with a microplastic concentration of 0.1 $\mathrm{g} / \mathrm{L}$, and P3 with a microplastic concentration of $1 \mathrm{~g} / \mathrm{L}$. The organ groups observed were the gastrointestinal, liver, gills, and gonads. Each treatment was repeated 3 times. The experimental unit used is one aquarium. Each aquarium is filled with water as much as $60 \mathrm{~L}$ with two rock aerators to maintain dissolved oxygen. Every aquarium used 5 tilapia fish with initial weight between 48 to 64 grams.

\subsection{Pisciculture}

Pisciculture is carried out to control the environmental condition during the experiment and ensure the survival fish obect which consist of two stages. Fish were acclimatized for 14 days with commercial feed 2 times a day on ad satiation. Water replacement and fish manure collection (by siphoning $10 \%$ of the container volume). After being acclimatizated the fish were tested by sprinkled microplastics on the water surface. The test was done for 14 days with the same feeding pattern as the acclimatization process. There was no water replacement and fish manure collection during the process. Water only added if reduction occured due to evaporation process.

During the 14 days of testing if fish die, the fish immediately dissected to collect the samples of the observed organs (gills, liver, gonads, and gastrointestinal). On the 14th day all fish were slaughtered and dissected to collect samples of the target organs. Organ samples then extracted to obtain microplastics contained on it. The surgery was also carried out on fish that were not given microplastic treatment in purpose of comparison. [16].

\subsubsection{Water quality measurement}

The water quality parameter measured were dissolved oxygen, temperature, $\mathrm{pH}$, and ammonia [17]. These parameters are water quality measuring standard for aquaculture. Dissolved oxygen, temperature, and $\mathrm{pH}$ measurements are tested every day in each aquarium to ensure that the water is still within the normal range for the fish life. The total ammonia parameter was measured at the beginning until the end of treatment.

\subsubsection{Microplastic extraction}

The fish were dissected and taken for gills, gastrointestinal, gonads, and liver, then each of the fish organs are placed in a test tube. The organs that have separated then added $10 \% \mathrm{KOH}$ solution until submerged (approximately 3 times of tissue volume) to destroy fish organs (organic matter). The test tube containing fish organs and $10 \% \mathrm{KOH}$ solution was covered with aluminum foil and allowed to stand for 48 hours at normal temperature. If in the first incubation period there are still fish organs that are not yet dissolved, then added $10 \% \mathrm{KOH}$ solution again until fully dissolved, continue with homogenization using a stirrer and left for 24 hours [18]. After the organ is destroyed then filtered using Whatman paper 42 which already contains the sample, closed and coated with aluminum foil, then dried in the oven at $70^{\circ} \mathrm{C}$ for 24 hours for identification process [19].

\subsubsection{Calculation of the number of microplastics}

The identification process was carried out using a microscope with 4 x 10 magnification [19]. The sample on Whatman 42 paper that has been dried was transferred to petri dish for identification. The microplastics in the petri dish divided into 4 or more parts for ease of observation. The petri dish placed on the object table, then set the macrometer and micrometer to focus the object. After obtaining the microplastic image, the next step is to calculate the number of microplastics in each organ [20].

\subsubsection{Data analysis}

Water quality data (DO, $\mathrm{pH}$, and temperature) are presented in the form of line graphs. Data were analyzed descriptively by comparing the measurement results of each parameter in each treatment. Parameter data for Total Ammonia $(\mathrm{mg} / \mathrm{L})$ is presented in the form of changes in Total Ammonia value $(\Delta \mathrm{TA})$, with the formula:

$$
\Delta T A=T A(\text { after })-T A \text { (before) }
$$

The value of $\triangle T A$ is plotted in a scatter diagram with the value of the concentration of microplastics according to treatment $(0,01 \mathrm{~g} / \mathrm{L} ; 0,1 \mathrm{~g} / \mathrm{L}$ dan $1 \mathrm{~g} / \mathrm{L})$. Relationship between microplastic concentration and $\Delta \mathrm{TA}$ value analyzed using a linear regression 
model. Data on the average number of microplastics in target organs were analyzed using a two-factor analysis of variance with replication. Factor difference in microplastic concentration as treatment and target organ factors as group observed data. After that, the data was further tested using the Least Significance Different method (Fisher's LSD test) [21]. To determine the target organ for MP (microplastic percentage) accumulation calculate by the formula:

$$
\begin{aligned}
& \text { Microplastic percentage } \\
& =\frac{\text { Microplastic value in the organ }}{\sum \text { Microplastic value in the organ }} \times 100 \%
\end{aligned}
$$

The greater the percentage of microplastic in the organ indicates that the organ has the potential to accumulate microplastics.

\section{Results and Discussion}

\subsection{Water temperature, $\mathrm{pH}$, and dissolved oxygen}

The parameters of temperature, $\mathrm{pH}$, and dissolved oxygen for all treatments were obtained values corresponding to the life of tilapia. Temperature parameters ranged from 25.80 to $29.27 \mathrm{C}$ (Figure 1), while the $\mathrm{pH}$ ranged from 7.21 to 7.77 (Figure 2), and for dissolved oxygen, it ranged from 6.60 to $10.50 \mathrm{mg} / \mathrm{L}$ (Figure 3). Average temperature values for P1, P2, and $\mathrm{P} 3$ respectively $27.22 \pm 0.83{ }^{\circ} \mathrm{C}, 27.42 \pm 0.85^{\circ} \mathrm{C}$, and $26.99 \pm 0.73{ }^{\circ} \mathrm{C}$. The average $\mathrm{pH}$ values for $\mathrm{P} 1, \mathrm{P} 2$, and $\mathrm{P} 3$ respectively $7.51 \pm 0.18,7.47 \pm 0.11$, and $7.47 \pm$ 0.16 . The average dissolved oxygen values for P1, P2, and $\mathrm{P} 3$ respectively were $7.78 \pm 1.45 \mathrm{mg} / \mathrm{L}, 7.73 \pm 1.55$ $\mathrm{mg} / \mathrm{L}$, and $8.03 \pm 1.43 \mathrm{mg} / \mathrm{L}$. Based on the average of these three parameters, each treatment was not significantly different. The water quality contained in this study is still suitable for the life of tropical fish, especially for fish temperature, $\mathrm{pH}$, and dissolved oxygen were 26 to $29.5^{\circ} \mathrm{C}, 7.20$ to $7.75,5.9$ to 10.2 $\mathrm{mg} / \mathrm{L}$ for each. This also shows that the presence of microplastics does not affect the parameters of temperature, $\mathrm{pH}$, and dissolved oxygen. According to [22], the average water quality for tropical freshwater fish at temperature about 26 to $30^{\circ} \mathrm{C}, \mathrm{pH}$ ranges from 5.0 to 8.5 , dissolved oxygen is 3.0 to $7.5 \mathrm{mg} / \mathrm{L}$.

Temperature is a physical parameter that affects the metabolic process of a living organism. Significant temperature changes can affect consumption level [23], stress level even mortality [24]. In this study, there was no significant temperature change, this was indicated by the active movement of tilapia, the feeding process, and fish were staying alive during the observation. The temperature value is in the suitable conditions for the survival of tilapia. The presence of microplastics for 14 days of observation did not affect the water temperature (figure 1). However, the increasing temperature can increase the concentration of microplastics in fish exposed to microplastics [25].
$\mathrm{pH}$ levels for each treatment show that no significant difference in this study. The presence of microplastic does not affect to $\mathrm{pH}$ in water either. Fluctuation in $\mathrm{pH}$ result from the changes of the rate of photosynthesis in response to daily photoperiod. As carbon dioxide accumulates in the water during the night, the $\mathrm{pH}$ falls [26]. The ideal $\mathrm{pH}$ range for freshwater aquaculture should range between 6.5 and 7.0, although a $\mathrm{pH}$ range of 6.1 to 8.0 is also considered suitable for survival [27].

Based on the results of this study, the presence of microplastics does not affect dissolved oxygen in water, but dissolved oxygen is needed for various forms of life including animals and plants in the waters. The use of dissolved oxygen for respiration in water is similar to the land organism. Aquatic animals have their mechanism in obtaining oxygen for respiration through their gills, while aquatic plants and phytoplankton require dissolved oxygen for respiration when there is no light for photosynthesis. The dissolved oxygen in water body increases because of the number of phytoplankton increases during algal photosynthesis on the day [28]. It is an important parameter in assessing water quality because of its effect on organisms living in water body. The dissolved oxygen levels that is too high or too low can harm aquatic life and affect water quality. [29] stated that low DO levels adversely affect fish growth and feed. When DO decreases from 6.5 to 3.0 or $1.5 \mathrm{mg} / 1$ the fish growth and feed consumption is reduced as same as utilization and innate immunity while fish performance increased significantly with the decrease of fish density that indicating stress [30].

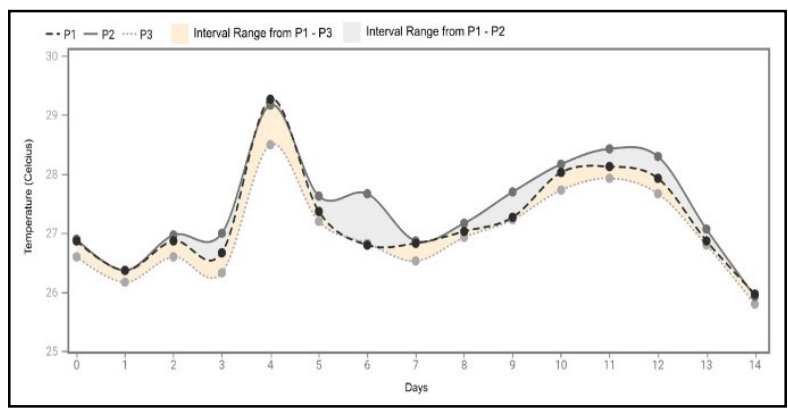

Fig. 1. Temperature change during treatment

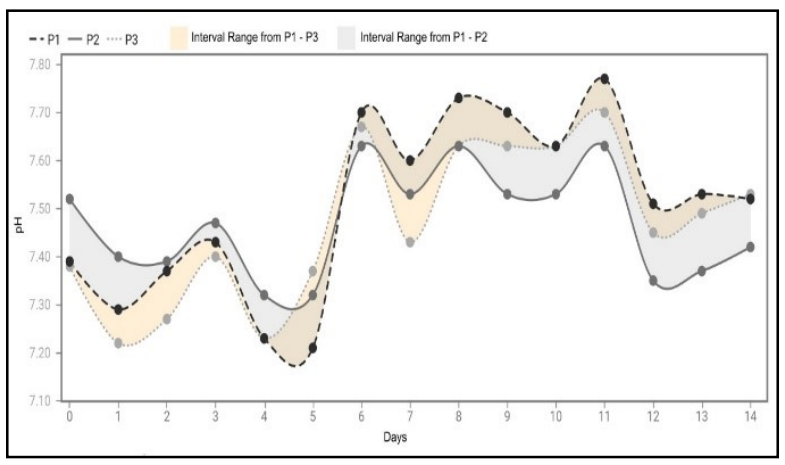

Fig. 2. $\mathrm{pH}$ change during treatment. 


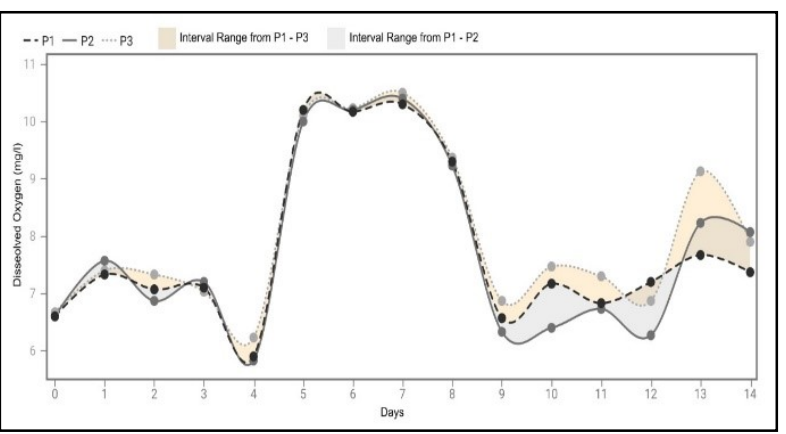

Fig. 3. Dissolved oxygen change during treatment.

The aquarium used rock aerator to maintain dissolved oxygen concentration during the research. Therefore, different concentrations of microplastic did not affect dissolved oxygen. The aquarium is placed in the room avoided from sunlight so the water temperature is likely similar although different microplastic concentration added. Water $\mathrm{pH}$ is influenced by temperature and dissolved oxygen and makes the $\mathrm{pH}$ value allows the same indication. Different symptoms will happen in total ammonia concentration correlated with microplastic concentration.

\subsection{Concentration relationship with total ammonia}

In this study, the result of the total ammonia at the beginning of the measurement in each treatment were $2.08 \pm 1.59 \mathrm{mg} / \mathrm{L}$ for $\mathrm{P} 1,2.00 \pm 0.87 \mathrm{mg} / \mathrm{L}$ for $\mathrm{P} 2$, and $2.50 \pm 0.87 \mathrm{mg} / \mathrm{L}$ for P3. At the end of the measurement in each treatment that is $0.17 \pm 0.14 \mathrm{mg} / \mathrm{L}$ for P1, $0.17 \pm$ $0.14 \mathrm{mg} / \mathrm{L}$ for $\mathrm{P} 2$ and $0 \mathrm{mg} / \mathrm{L}$ for $\mathrm{P} 3$. The results obtained are in the form of a linear line that shows the more concentration of microplastics given for 14 days of the treatment the total ammonia is decreased (Figure 4).

Ammonia is one of the parameters of water quality that is very influential on aquaculture activities. Ammonia is an important aspect because it can affect the survival of an organism. Microplastics do not have a direct effect on ammonia in the waters, because they are abiotic components that are difficult to decompose. Microplastics are known to decompose due to physical influences and less by decomposing bacteria [31]. The total ammonia in this study has decreased because microplastics contained in freshwater will become a home for nitrogen-decomp [9]. This statement reinforced by [32], that there is nitrogen degradation using a plastic biofilter form of scrub is $26.3 \%$. The function of microplastics becomes a home for bacteria to degrade the total ammonia in water environment. In another study, it was shown that the transfer rate of nitrite and ammonia with the addition of microplastics (polyvinyl chloride) decreased according to the given concentration [33]. As in this study, the higher concentration the lower the ammonia value. However, this condition is also unideal for other livings because microplastics can enter tissues and cells, causing potential damage in tissues and cells even death [7].

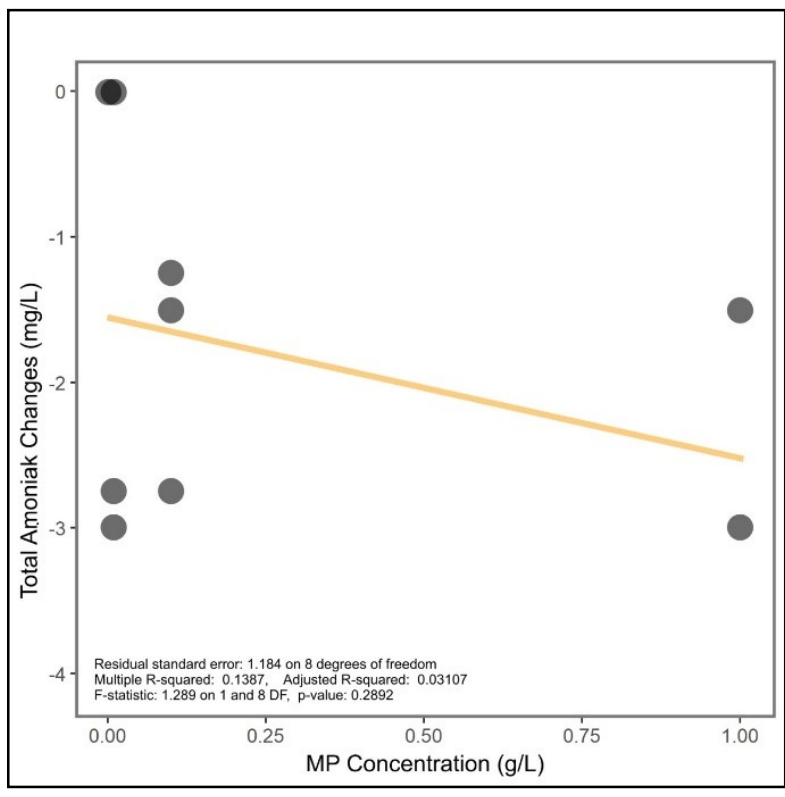

Fig. 4. Microplastic concentration relationship with total ammonia

\subsection{Number of microplastics in organs}

The number of microplastics exposure in the fish gastrointestinal fish has the highest value than other organs in all treatments (Figure 5). In the P3 treatment with a microplastic concentration of $1 \mathrm{~g} / \mathrm{L}$, the value was $3.11 \pm 0.54 \mathrm{~L}-1$, while for $\mathrm{P} 2$ it is $2.87 \pm 0.30 \mathrm{~L}-1$ and for $\mathrm{P} 1$ it is $2.19 \pm 0.37 \mathrm{~L}-1$. The value of microplastics in the gills at P1, P2, and P3 is $1.48 \pm 0.25 \mathrm{~L}-1,1.74 \pm 0.22$ $\mathrm{L}-1$, and $2.37 \pm 0.47 \mathrm{~L}-1$, respectively (Figure 5). Microplastics exposure in liver respectively $1.06 \pm$ 0.06 L-1 (P1), $1.38 \pm 0.35$ L-1 (P2), $2.35 \pm 0.59$ L-1 (P3). Microplastics exposure in gonads respectively $1.12 \pm 0.26 \mathrm{~L}-1(\mathrm{P} 1), 1.47 \pm 0.37 \mathrm{~L}-1$ (P2), $1.71 \pm 0.61$ L-1 (P3) (Figure 5). Microplastics were accumulated in tilapia are spread to several organs, those are gastrointestinal $(78,9 \%)>$ gill $(10,3 \%)>\operatorname{liver}(6,6 \%)>$ gonad (4,2\%) (Figure 6). This shows that microplastics in the aquatic environment enter to gastrointestinal through feeding.

The number of microplastics exposure in the gastrointestinal of fish has the highest value than other organs in all treatments (Figure 5). The gastrointestinal in Fish has high potential for exposure to microplastics that enter through the mouth, the gastrointestinal then accumulated in the body of tilapia [14]. According to [16] the higher concentration of microplastics in the waters the more fish will be exposed to microplastic. This is following the number of microplastic exposure found in the gastrointestinal.

In the gill, the microplastic is smaller than the gastrointestinal because the gills are not designed to absorb food but oxygen, which is used for fish respiratory [34]. This situation has the potential for microplastic adsorption into the tissue and blood so it will spread throughout the body and cause tissue damage [35]. In gills the microplastics can attach to mucus membranes. Microplastics enter the gills through 
the cavity which is then filtered and settles in the layer due to the presence of mucus [36]. The presence of this mucus is due to stimulation of the fish body as means of self-defense [37]. The number of microplastics in the gills also follows the given microplastic concentration.

This situation is harmful for the survival of the fish because microplastics exposure can damage fish tissue and can even enter cells by sizes up to $70 \mu \mathrm{m}$ [38]. Based on the research [39], obtained that all tilapia juvenile organs are microplastics exposed. It may cause anemia, impaired liver metabolism, biochemical disorders [35], and inhibition of AChE activity in the brain [7].

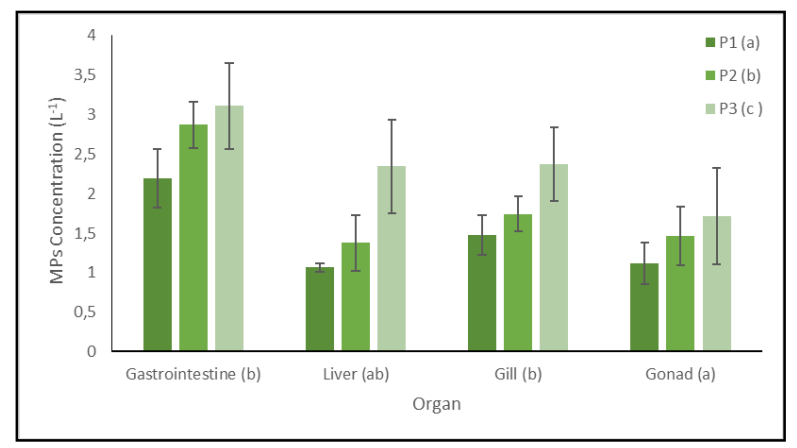

Fig. 5. The number of microplastics in tilapia organs

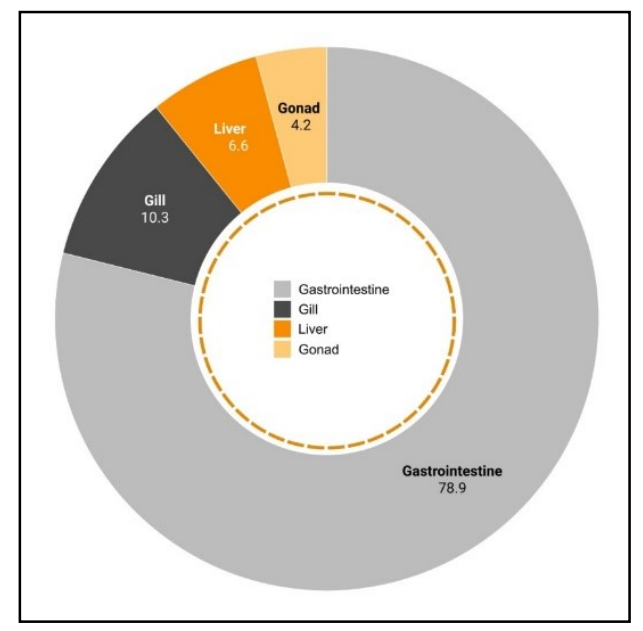

Fig. 6. Microplastic percentage

\section{Conclusion}

Microplastics at high concentrations in water cause the decrease in the total value of ammonia and do not affect the value of water temperature, $\mathrm{pH}$, and dissolved oxygen. Microplastics were found in the digestive organs, liver, gills, and gonads. The digestive tract of tilapia is the organ with the most microplastics after 14 days of exposure. We would like to thank the Institute for Research and Community Service, University of Sultan Ageng Tirtayasa (LPPM-UNTIRTA) that has provided research grants under the "Penelitian Dosen Pemula (PDP)". Our gratitude also goes to the entire team of the Water Resources Management Laboratory and Aquaculture Laboratory, University of Sultan Ageng Tirtayasa, EA Solahudin, EM Rizki, W
Halwatiyah, H Istiqomah, H Maharani, and H Wahyudin for the assistance during the research.

\section{References}

1. F.S. Hamid, M.S. Bhatti, N. Anuar, N. Anuar, P. Mohan, A. Periathamby. Waste Manag Res. 36, 10 (2018)

2. K. Jabeen, L. Su, J. Li, D. Yang, C. Tong, J. Mu, H. Shi. Environ Pollut. 221 (2017)

3. A.A. Manalu, S. Hariyadi, Y. Wardiatno. AACL Bioflux. 10, 5 (2017).

4. J. Zhu, Q. Zhang, Y. Li, S. Tan, Z. Kang, X. Yu, W. Lan, L. Cai, J. Wang, H. Shi. Sci Total Environ. 658 (2019).

5. J.F. Provencher, J. Ammendolia, C.M. Rochman, M.L. Mallory. Environ Rev. 27, 3 (2019).

6. M.C. Rillig, A. Lehmann, A.A. de Souza Machado, G. Yang. New Phytol. 223, 3 (2019).

7. T. Miranda, L.R. Vieira, L. Guilhermino. Int J Environ Res Public Health. 16, 16 (2019).

8. J.R. Jambeck, R. Geyer, C. Wilcox, T.R. Siegler, M. Perryman, A. Andrady, R. Narayan, K.L. Law. Science. 347, 6223 (2015).

9. X. Chen, X. Chen, Y. Zhao, H. Zhou, X. Xiong, C. Wu. Sci Total Environ. 719 (2020).

10. Y.A. Hidayat, S. Kiranamahsa, M.A. Zamal. AIMS Energy. 7, 3 (2019).

11. S. Ziajahromi, A. Kumar, P.A. Neale, F.D.L Leusch. Sci Total Environ. 671 (2019).

12. A.H. Ramadan, E. Sembiring. E3S Web of Conferences. 4 (2020).

13. C. Pinheiro, U. Oliveira, M. Vieira. J Aquac Mar Biol. 5, 6 (2017).

14. F.R. Khan, Y. Shashoua, A. Crawford, A. Drury, K. Sheppard, K. Stewart, T. Sculthorpe. Toxics. 8, 2 (2020).

15. M.M. Dey, M.V. Gupta. Aquac Econ Manag. 4 (2000).

16. B. Jovanović, K. Gökdağ, O. Güven, Y. Emre, E.M. Whitley, A.E. Kideys. Mar Pollut Bull. 130 (2018).

17. F. Simões, dos S., A.B. Moreira, M.C. Bisinoti, S.M.N. Gimenez, M.J.S Yabe. 8, 5 (2008).

18. I.L.N. Bråte, R. Hurley, K. Iversen, J. Beyer, K.V. Thomas, C.C. Steindal, N.W. Green, M. Olsen, A. Lusher. Environ Pollut. 243 (2018).

19. J.S. Silva-Cavalcanti, J.D.B. Silva, E.J. de França, M.C.B. de Araújo, F. Gusmão. Environ Pollut. 221 (2017).

20. J. Li, X. Qu, L. Su, W. Zhang, D. Yang, P. Kolandhasamy, D. Li, H. Shi. Environ Pollut. 214 (2016).

21. H. Finner. Ann Stat. 27, 1 (1999).

22. M.E. Azim, D.C. Little. Aquaculture. 283 (2008).

23. O. Iwaliye, G.K. Moodley, V.R.A. Deborah. Ocean Science Journal. 56, 2 (2021). 
24. P. Phrompanya, P. Panase, S. Saenpet, K. Saenpet. Fisheries Science. 87, 4 (2021).

25. B. Wen, N. Zhang, S.R. Jin, Z.Z. Chen, J.Z. Gao, Y. Liu, H.P. Liu, Z. Xu. Aquatic Toxicology 195 (2018).

26. A.J. Makori, P.O. Abuom, R. Kapiyo, D.N. Anyona, G.O. Dida. Fisheries and Aquatic Sciences. 20 (2017).

27. V.E. Herawati, J. Hutabarat, Pinandoyo, O.K. Radjasa. Hayati Journal Biosience. 22, 4 (2015).

28. K. Kunlasak, C. Chitamat, N. Whangchai, J. Promya, L. Lebel. International Journal of Geosciences. 4 (2013).

29. M.A. Tawwab, A.E. Hagras, H.A.M. Elbaghdady, M.N. Monier. Aquacult Int. 23 (2015).

30. M.A. Tawwab, A.E. Hagras, H.A.M. Elbaghdady, M.N. Monier. Journal of Applied Aquaculture. 26 (2014).

31. A. McCormick, T.J. Hoellein, S.A. Mason, J. Schluep, J.J. Kelly. Environ. Sci. Technol. 48 (2014).

32. Y.S. Al-Hafedh, A. Alam, M.A. Alam. Aquac Eng. 29 (2008).

33. K. Song, Z. Li, D. Liu, L. Li. ACS Omega. 5, 37 (2020).

34. M. Hamed, H.A.M. Soliman, A.G.M. Osman, A.E.D.H. Sayed. Environ Sci Pollut Res. 27, 13 (2020).

35. J. Ding, S. Zhang, R. Rajanatovo, H. Zhou, W. Zhu. Environ Pollut. 238 (2018).

36. J.A. Watts, M.A. Urbina, R. Goodhead, J. Moger, C. Lewis, T.S. Galloway. Environ Sci Technol. 50, 10 (2016).

37. F. Zhu, C. Zhu, C. Wang, C. Gu. Bull Environ Contam Toxicol. 102, 6 (2019).

38. G. Fabian. Lymphology. 16, 1 (1983).

39. M. Hamed, H.A.M. Soliman, A.G.M. Osman, A.E.D.H. Sayed. Chemosphere. 228 (2019). 